\title{
Comparison of the Level of Personnel Work in the Czech Republic and Slovakia
}

\author{
Lukáš Smerek $^{1, * \mathbb{D}}$, Milota Vetráková ${ }^{1}$, Šárka Čemerková ${ }^{2}$ and Vojtěch Malátek ${ }^{2}$ \\ 1 Faculty of Economics, Matej Bel University, Tajovského 10, 97590 Banská Bystrica, Slovakia; \\ milota.vetrakova@umb.sk \\ 2 School of Business Administration in Karvina, Silesian University, Univerzitní Náměstí 1934/3733, \\ 73340 Karviná, Czech Republic; cemerkova@opf.slu.cz (Š.Č.); malatek@opf.slu.cz (V.M.) \\ * Correspondence: lukas.smerek@umb.sk; Tel.: +421-48-446-2732
}

Citation: Smerek, L.; Vetráková, M.; Čemerková, ̌̌.; Malátek, V. Comparison of the Level of Personnel Work in the Czech Republic and Slovakia. Sustainability 2021, 13, 287. https://doi.org/10.3390/su13010287

Received: 4 December 2020

Accepted: 23 December 2020

Published: 30 December 2020

Publisher's Note: MDPI stays neutral with regard to jurisdictional clai$\mathrm{ms}$ in published maps and institutional affiliations.

Copyright: (C) 2020 by the authors. Licensee MDPI, Basel, Switzerland. This article is an open access article distributed under the terms and conditions of the Creative Commons Attribution (CC BY) license (https:// creativecommons.org/licenses/by/ $4.0 /)$.

\begin{abstract}
After 1989, the countries of Eastern and Central Europe began to undergo significant social and economic changes associated with the process of transformation of the economy into a market economy. Transformation is not only associated with the creation of a business environment, with the formation of new legal and institutional mechanisms, but also with a change in the thinking and behavior of people including employees, managers and owners. The paper aims to identify important processes and trends in developing human resource management in companies in the Czech Republic and the Slovak Republic. We conducted the questionnaire survey in 2018 and 2019 in various areas of business. We obtained the opinions of respondents from 1542 companies. In the research, we assume that in the conditions of a market economy compared to a centrally managed economy, employees are the most important source of development and performance of companies. Descriptive statistics were used to characterize the sampling unit. The other methods used to evaluate data in the paper were the Mann-Whitney test and Spearman Correlation coefficient. The research revealed that despite a long common history, differences in the field of personnel work have arisen in the last 20 years of the independent existence of the Czech Republic and the Slovak Republic. The only exception is employee care. It was also found that in the Czech Republic the strategic orientation predominates, on the contrary, companies in the Slovak Republic focused on operational processes. Differences were also found in the way of adaptation and further training of employees. The results of the findings can be used to design processes with the highest positive impact on business performance.
\end{abstract}

Keywords: enterprises; human resources; human resource management; sociological research; trends of HRM

\section{Introduction}

Slovak Republic (Slovakia) and the Czech Republic are connected by a common 74year history, which began with the declaration of Czechoslovakia in 1918. From the point of view of political and economic development, a new state called Czechoslovakia was established. Compared to the more industrially developed Czech Republic, Slovakia found itself in a strong competitive environment. The reason was the disproportions between the individual areas of the economy caused by the internal structure of industry, agriculture and infrastructure in Slovakia and the Czech Republic. The implemented reforms led to economic recovery and Czechoslovakia gradually joined the developed countries of the world. The benefit of the new state grouping for Slovaks was the raising of the culture and self-confidence of the Slovak nation. Subsequent developments, but which led to a decline in restructuring and development of industry due to the great economic crisis in the years 1929 to 1933.

After the Second World War, Czechoslovakia became part of the so-called Eastern Bloc, a typical feature of which was the centrally planned economy. Only a few employers were 
aware of the importance of people in the work process, their priority over other sources of production.

In 1989, the centrally planned economies of the Eastern bloc countries collapsed across Europe and gradually were turned into market economies. With the abolition of the Communist Party's political monopoly, economic reforms and fundamental democratic changes began. These changes allowed companies to democratically manage their own development. This was reflected in particular in the ability to decide independently on staffing issues. The beginning of the restructuring of independent personnel work was related to the euphoria of many managers, but on the other hand, there was distrust and resistance to managing people's work. This reflected previously implemented staff and personnel policies in companies during the communist regime. During this difficult time, a new HRM system was being developed. A significant problem in companies was the general lack of preparedness of managers for human resource management. Therefore, everything reminiscent of previous periods was rejected in the companies. The concentration of efforts to implement the new human resources management system proved to be problematic, as there was a lack of readiness and virtually no experience with new approaches to human resources management in this area. The inertia of staff and personnel work in large companies maintained the procedures of relatively well-developed personnel activities, which were cleansed of political and ideological goals. The transition from a centrally planned economy to a market economy brought several new challenges for the practical implementation of personnel work due to changes in legislation, higher expectations and growing employee awareness. This was also reflected in access to information, mobility, freedom of decision-making, the new role of trade unions and systematic changes in corporate governance and ownership. Guidelines for the creation and application of the system of personnel activities were sought by the then human resources managers abroad, later by participating in conferences and workshops.

Following the mutual agreement in December 1992, Czechoslovakia split into 2 independent states on 1 January 1993, namely the Czech Republic and the Slovak Republic. Despite the divisions, the cultural, political and economic relations that developed between the two nations during the common state have persisted to these days. Regional and linguistic proximity, a common history, a similar mentality and business cooperation are attributes that help to gain a foothold in worldwide competition in a globalized world.

More than thirty years have passed since the process of transformation of the economies of the Eastern bloc countries began. While the beginning of the transformation process is clear, its completion is debatable. According to [1], it only ends when the regulatory mechanism of a market economy is functional with the ability to generate sustainable growth and when the structural distortions attributable to the previous economic system are removed. The above-mentioned development and changes have led us to try to know the level of human resource management in companies operating in Slovakia and the Czech Republic. The study of selected HRM processes after 1989 took place only sporadically in Slovakia and the Czech Republic. The results of the first comprehensive survey of the level and all HRM processes in Slovakia were presented in 1997 [2,3] and in the Czech Republic in 1998 [4]. A comparison of the development of personnel work and trends in the development of HRM processes in Slovakia and the Czech Republic has not yet been made. For this purpose, research has been organized to verify whether management practices have been designed over the past 30 years to enable managers in today's market conditions through effective management to maintain a high level of employee engagement and ensure performance and long-term sustainability. In this article, we aim to respond to the four research questions as follows:

RQ1: Which processes in personnel work are mostly dealt with by companies in the Czech Republic and the Slovak Republic?

RQ2: Is it possible to identify different shares of HRM implementation in companies operating in the Czech and Slovak Republics? 
RQ3: Which problems in personnel work do companies in the Czech Republic and Slovakia pay the most attention to?

RQ4: What trends (approaches) to HRM are used by multinational and local enterprises?

From a content point of view, we will evaluate the different opinions of managers on human resources (or HRM), and point out common and different trends in the development of personnel work in both countries. The aim of the paper is therefore to identify important processes and trends in HRM development in companies in the Czech Republic and the Slovak Republic and quantify any differences in HRM processes.

\section{Theoretical Background}

The success of enterprises largely depends on the ability of managers to manage themselves and the work of others resulting in the efficient use of all production resources with increasing satisfaction of customers, employees and owners. Human resources are becoming an activating factor in the development of companies [5]. If we examine the genesis of the development of views on the position of people in the work process, we must state that the philosophy of human resource management has changed as theory and practice have been formed in economics and management.

The theory of economics and management also had a decisive influence on the formation of opinions on personnel work. Personnel work generally means working with people in the work process, regardless of the degree of its development. It is based on personnel administration, i.e., keeping records of employees and ensuring all procedures related to employment.

In the post-World War II period, managers were looking for new ways to survive in the marketplace and gain an advantageous position. To achieve prosperity, they activated all elements of the work process [6]. This stage of personnel work can be marked as personnel management. It is a process of actively and systemically influencing the behavior of employees to achieve the desired effect. The position of employees is at the same level as other resources of the company.

In the countries of the so-called Eastern bloc after the Second World War, a centrally planned economy was introduced, which was also reflected in the formation of personnel work in companies. Since 1970, personnel work has been guided by a uniform personnel policy adopted on a central (national) platform [7]. The principles and methods of carrying out individual processes were determined directly from the state level. Only a person with the required political affiliation, whose decision-making power in HRM was significantly limited, could become the manager of the company.

The operational approach to employees, typical of personnel management in many enterprises, was gradually replaced by a strategic approach in the second half of the twentieth century. This strategic approach is also reflected in the content of personnel work in human resource management (HRM). Its main characteristics include the recognition of man as a bearer of the workforce with his competencies and skills. Such a person is considered to be the most important source of the enterprise [8-11].

HRM includes processes that are tied to the employee's employment. The following can be ranked here, such as: (1) Finding and recruiting suitable employees, identifying and recruiting capable and competent employees associated with job analysis, human resource planning, until the release of those who are unable to provide the expected work performance; (2) provision of work tasks and support of employees based on processes such as creating human resources strategy and policy, adaptation and training of employees, their evaluation, human resources department services, personnel information system services, personnel controlling, human resources audit; and (3) stabilization of competent employees largely dependent on processes, such as career development, talent management, job motivation, performance management, remuneration and employee benefits, safety and protection of health at work, employment relations, employee care, internal flexibility.

Managers' orientation towards employees as human resources emphasizes the use of employees' work, the personality of people, determined by their own needs and val- 
ues [12]. Compared to other resources, human resources are capable of development and appreciation, bringing higher added value than their value. Only people can find ways to increase quality, improve management, use technology and other resources in the company. Economists refer to this human ability as "capital" [13,14].

Unlike physical capital, human capital has an intangible and personal character. It consists of acquired knowledge, skills, habits, motivation and energy of people, which are used in a certain period. Ref. [15] opens a discussion on a new approach to HRM, which he calls human capital management. He believes that managers must understand the complexities of measuring human capital and link the strategy of managing and using human capital with the strategic management of human resources.

The management of human capital is debatable as human capital is the property of its bearer and not the property of the enterprise [16]. The bearer of human capital, and thus, the employee decides which part of the employee's knowledge, abilities and skills will be used by the employer [17]. At the same time, the value of human capital is influenced by its bearer, but also by upbringing, education, social, cultural and work environment in which the employee occurs [18]. However, an employer who invests in employee development expects that the investment will return to him/her, nevertheless, it is questionable whether he is even able to manage the human capital of the employee. We agree with the views of $[19,20]$, according to which the issue of human capital is part of the strategic management of human resources based on the measurement and analysis of processes leading to their evaluation and diagnostics.

In a market economy, capable employees with the necessary knowledge and skills who can work in both domestic and intercultural environments become a competitive advantage [21] and give the expected work performance [22]. Satisfaction with accepted HRM practices and processes is a prerequisite for the desired work performance [23]. According to [24], managing human resources internationally focuses on typical HRM processes, such as workforce planning, recruitment, selection, training, development, performance appraisal, and compensation in multinational corporations. HRM brings together people of different cultures and creates the prerequisites for integrating diversity into the values and visions of a corporation. Working with people in an international environment need to manage the additional challenge of successfully navigating various institutional, social, cultural, political, and economic environments [25,26]. Strategic HRM, applied in the domestic and international environment, emerged as a dominant approach to HRM policy during the past 30 years. However, during the last decade, a new approach to HRM has evolved. According to [27], this approach has been labelled sustainable HRM. Emphasis is placed on the ecological, ethical and social use of resources in the company and sustainability is promoted in human resource management [28-31]. Research studies [32,33] suggest that pro-environmental HRM practices, including hiring, training, appraisal and motivation support the development of sustainable organizational culture. The sustainable approach to HRM assumes that managers and owners can find ways to improve day-to-day operations, employee performance, use of machinery and equipment, materials, information, and other inputs [34,35].

The only way to sustainable development and gaining a competitive advantage in the market is to employ and support people who can work, use and develop their knowledge potential and have a sustainable relationship with the environment in which they work. The results of the study by [36] confirm the interaction between ecological behavior of employees and corporate environmental performance. Gaining a relatively stable and strategic position of the enterprise in the global market requires fundamental changes in the thinking of managers and HRM. According to [37], these are mainly changes that will support employee engagement, their job satisfaction and sustainability in the company. The general aim of the HRM is to ensure that an enterprise will be able to employ people in a way to succeed in achieving its objectives.

The connection of theoretical knowledge of HRM with practical approaches of managers to HRM processes is the subject of constant research. The reason is the fact that 
people are the core resources of any enterprise and many types of foreign research. Research studies [38-42] have documented positive effects of various personnel work policies and practices on employee performance, as well as enterprises performance and competitiveness. However, the lack of a skilled workforce, declining reliability and employee responsibility are causing increasing fluctuation and problems in HRM that need to be addressed. According to [43-45] managers of companies, responding to the internal and external situation of the company, deal with those HRM processes that they consider a priority in securing the company's goals.

Even though until 1993 the Czech and Slovak Republics were part of one state, the level of individual economic entities was different. This was also reflected in personnel work. In addition, 27 years have passed since the partition of Czechoslovakia. The development of personnel work in these two countries has been different. Surveys in the Czech Republic show that the most important processes under the responsibility of top managers include performance management, employee evaluation, adaptation, training and development, and labor analysis [46]. In the Slovak Republic, managers place emphasis mainly on recruiting and hiring employees, remuneration, education and development, adaptation and personnel administration [47]. To confirm this assumption, we have formulated the following hypotheses:

Hypothesis 1 (H1). Enterprises operating in the Czech Republic are more engaged in strategically focused processes, such as strategy creation, planning, job analysis, employee adaptation and talent management.

Hypothesis 2 (H2). Enterprises operating in Slovakia are more focused on operationally oriented processes, such as recruiting employees, termination of employment and personnel administration.

Hypothesis 3 (H3). There is a dependence between the most common problems in personnel work and the implementation of individual HRM processes.

\section{Materials and Methods}

The object of the research are companies operating in the Czech Republic and Slovakia. When characterizing companies, we accept the division according to the recommendation of the European Commission 2003/361/EC, which is based on the number of employees and annual turnover [48] into micro, small and medium-sized enterprises. A characteristic feature of the economy in the countries of Central Europe is the predominance of small and medium-sized enterprises (SMEs). The SME sector is an important driver of business, growth, innovation and competitiveness and is a major employer. These are companies with up to 249 employees, which make up $99 \%$ of all companies and employ almost $75 \%$ of workers in the private sector.

In comparison with the conditions for doing business in Slovakia with other Central European countries, the share of SMEs is higher and makes up $99.9 \%$. Of the $560,521 \mathrm{com}-$ panies, 559,841 are SMEs and $680(0.1 \%)$ are large companies. Compared to other countries, the business environment in Slovakia is worsened mainly by the administrative and timeconsuming nature of establishing and operating companies, instability and opacity of the legislative environment, weak law enforcement and long-standing litigation, high tax and levy burden, persistent practices of clientelism and corruption.

Of the number of 1,154,687 enterprises in the Czech Republic, SMEs make up 1,152,735, which is $99.83 \%$ and employ almost $60 \%$ of economically active entities. Problems with doing business in the Czech Republic are similar and affect the payment morale of some entrepreneurs, the complexity of the tax system, which leads to various tax evasion, law enforcement, complex administrative burdens, dysfunctional venture capital market.

The transformation of the Czech and Slovak economy into a market economy is associated with the development of marketing and financial activities of companies on an international scale. The management of existing companies had to deal with many personnel issues related to the dismissal and restructuring of employees, changes in motivation, 
performance management, training and human resources development. Estimating and using the work potential of employees suitable for the needs of the company is much more demanding than materially and technically planning the volume of production, making technological changes in the work process. The subject of the research is the current HRM processes and the level of personnel work in enterprises in the Czech Republic and the Slovak Republic.

Data collection about HRM in companies in the Czech Republic and Slovakia was carried out by the method of sociological questioning using online and print questionnaires. The questionnaire contained 24 questions focused on HRM processes, including problems and proposals for measures to change and trends in the development of personnel work. We obtained the data in person or online from human resources departments and persons responsible for personnel work in companies. Together, we addressed 30,000 companies in the 2018 and 2019. In total 1542 HR managers represented 652 enterprises in the Slovak Republic (SK) and 890 in the Czech Republic (CZ) (Table 1), which represents 5\% response rate of respondents. The received numbered data were rewritten into a data matrix in MS Excel. SPSS SW was used for statistical analysis.

Table 1. Size of the enterprises surveyed.

\begin{tabular}{|c|c|c|c|c|c|c|c|c|c|c|c|c|c|c|c|}
\hline \multirow{3}{*}{ Enterp. } & \multicolumn{15}{|c|}{ Number of Employees } \\
\hline & \multicolumn{3}{|c|}{$<10$} & \multicolumn{3}{|c|}{$10-49$} & \multicolumn{3}{|c|}{$50-249$} & \multicolumn{3}{|c|}{$\geq 250$} & \multicolumn{3}{|c|}{ Total } \\
\hline & $\mathrm{CZ}$ & SK & $\sum$ & $\mathrm{CZ}$ & SK & $\sum$ & $\mathrm{CZ}$ & SK & $\sum$ & $\mathrm{CZ}$ & SK & $\sum$ & $\mathrm{CZ}$ & SK & $\sum$ \\
\hline Local & 68 & 87 & 155 & 128 & 110 & 238 & 212 & 120 & 332 & 98 & 64 & 162 & 506 & 381 & 887 \\
\hline MNC & 24 & 37 & 61 & 64 & 44 & 108 & 153 & 102 & 255 & 143 & 88 & 231 & 384 & 271 & 655 \\
\hline Total & 92 & 124 & 216 & 192 & 154 & 346 & 365 & 222 & 587 & 241 & 152 & 393 & 890 & 652 & 1542 \\
\hline
\end{tabular}

In the sample according to the number of employees, SMEs predominate in local enterprises (81.74\%) and in multinational companies the share of SMEs (64.73\%) is lower, which corresponds to the structure of local and multinational enterprises. For small companies, the local nature of management prevails, with the growth of the size of companies, multi-nationally managed companies begin to dominate.

The size of enterprises according to the number of employees and the representation of foreign capital in multinational enterprises affect the processes and level of personnel work. We assume that the level of personnel work will be higher in large and multinational companies than in small and medium-sized enterprises.

We used the Mann-Whitney $U$ test to process the obtained data needed to verify the hypotheses. The Mann-Whitney $U$ test can be used to answer the questions concerning the difference between groups. This test has the great advantage of possibly being used for small samples of subjects. In the field of behavioral sciences, the Mann-Whitney $U$ test is one of the most commonly used non-parametric statistical tests [49]. Its null hypothesis (H0) assumes that the two groups come from the same population. In other words, it assumes that the two independent groups are homogeneous and have the same distribution. The alternative hypothesis (H1) against which the null hypothesis is tested assumes that the first group data distribution differs from the second group data distribution. The Mann-Whitney test is based on the comparison of each observation from the first group with each observation from the second group [50]. We performed testing at a level of significance of $95 \%$.

We used a nonparametric Spearman correlation coefficient to verify the dependence between the individual variables. "We use it to determine whether two variables are correlated, for example, when the assumption of normality of measured data is violated" [51]. In this way, we test the null hypothesis of zero value of the theoretical Spearman correlation coefficient, i.e., that the quantities $X$ and $Y$ are order-independent compared to the alternative hypothesis that the quantities $\mathrm{X}$ and $\mathrm{Y}$ are order-dependent. 


\section{Results}

According to the job classification in the surveyed companies in Slovakia, personnel work is in the responsibility of managers and clerks of human resources departments (37.1\%), economic department clerks and line managers (31.1\%), owners and top managers $(26.8 \%)$, secretaries of the top manager (1.8\%) and outsourcing (3.2\%). In the Czech Republic, personnel work is mainly in the competence of managers of individual organizational units $(47.3 \%)$, human resources managers $(13 \%)$, personnel clerks $(26.7 \%)$, others $(9 \%)$ or is provided with the use of outsourcing ( $4 \%$ ). The size of companies in Slovakia and the Czech Republic also corresponds to the professional provision of human resources. In small enterprises $(73.4 \%)$, mostly in addition to other work, individual personnel work processes are performed by one employee, in medium-sized enterprises by one to two employees $(46.6 \%)$ and by three employees $(26.8 \%)$. The emphasis on personnel work is increasing in large companies, where personnel work is divided between 3 and 4 employees $(82.1 \%), 5$ (5.8\%) and more employees (12.1\%).

To be able to answer the research question RQ1, the respondents were asked which of the HRM processes they implemented in their company. The obtained results showed that in the practice of personnel management in companies, different attention is often paid. In the Czech Republic, most companies focus on employee adaptation, performance appraisal and management, and job analysis. In Slovakia, the first place was taken by the recruitment of employees, followed by the administration and adaptation of employees, for more details see Table 2.

The Mann-Whitney $U$ test was used for individual personnel processes to assess the statistical significance of the difference between the implementation of processes in the Czech Republic and the Slovak Republic. Table 2 shows the Mann-Whitney U test values, critical values and $p$-values comparing the implementation of each process in the Czech Republic and Slovakia.

Table 2. The difference in the use of HRM processes.

\begin{tabular}{|c|c|c|c|c|c|c|c|}
\hline Implemented Processes & $\mathbf{U}$ & $\mathbf{Z}$ & $\begin{array}{c}\text { Asymp. Sig. } \\
\text { (2-Tailed) }\end{array}$ & $\mathrm{CZ}$ & CZ Order & SK & SK Order \\
\hline Creating strategies, policies and other plans & 258589 & -4.612 & $0.000 *$ & $74.83 \%$ & 4 & $63.96 \%$ & 6 \\
\hline Planning the number and structure of employees & 276151 & -2.096 & $0.036^{*}$ & $74.61 \%$ & 5 & $69.79 \%$ & 4 \\
\hline Job analysis & 215755 & -10.463 & 0.000 * & $76.40 \%$ & 3 & $50.77 \%$ & 9 \\
\hline Recruitment of employees & 258221 & -4.856 & $0.000 *$ & $69.21 \%$ & 7 & $80.21 \%$ & 1 \\
\hline Adaptation of employees & 227934 & -10.972 & $0.000 *$ & $91.69 \%$ & 1 & $70.25 \%$ & 3 \\
\hline Training and further education & 276860 & -1.970 & $0.049 *$ & $73.60 \%$ & 6 & $69.02 \%$ & 5 \\
\hline Talent management & 227493 & -8.437 & $0.000 *$ & $53.03 \%$ & 12 & $31.44 \%$ & 13 \\
\hline Determining the value of work (creation of a wage system) & 200124 & -12.08 & $0.000 *$ & $67.53 \%$ & 8 & $36.50 \%$ & 11 \\
\hline Employee care & 278889 & -1.586 & 0.113 & $67.53 \%$ & 8 & $63.65 \%$ & 7 \\
\hline Evaluation and management of employee performance & 208230 & -13.206 & $0.000 *$ & $89.89 \%$ & 2 & $61.66 \%$ & 8 \\
\hline Dismissal of employees (termination of employment) & 268804 & -2.989 & $0.003 *$ & $31.91 \%$ & 13 & $39.26 \%$ & 10 \\
\hline Personnel controlling & 237314 & -7.087 & $0.000 *$ & $53.48 \%$ & 11 & $35.28 \%$ & 12 \\
\hline Personnel administration & 261118 & -4.123 & $0.000 *$ & $62.70 \%$ & 10 & $72.70 \%$ & 2 \\
\hline
\end{tabular}

* Statistically significant difference at the 0.05 level (2-tailed).

The calculated critical values and $p$-values show that there is a 1 HRM process, the implementation of which did not confirm a statistically significant difference between companies in the Czech Republic and Slovakia. This process is employee care. In all other processes, we identified statistically significant differences. When looking for an answer to RQ2 we, thus, concluded that due to the existence of even only one process, which is implemented in the Czech Republic and Slovakia, the answer to this question is negative.

In strategic processes, the difference in favor of the Czech Republic is confirmed; on the contrary, in the Slovak Republic, increased attention is on everyday operations. We 
can, therefore, state that in the Czech Republic more companies are engaged in creating strategies, policies and other plans, planning the number and structure of employees, job analysis, employee adaptation, training and further education, talent management, determining the value of work, employee evaluation and personnel controlling. On the contrary, in the Slovak Republic, companies are more concerned with recruiting employees, terminating employment and personnel administration. We thus accept hypotheses $\mathrm{H} 1$ and $\mathrm{H} 2$. Table 3 provides a more detailed overview of the differences in personnel processes in the Czech Republic and the Slovak Republic.

Table 3. Difference in selected personnel processes.

\begin{tabular}{|c|c|c|c|c|c|}
\hline & $\mathbf{U}$ & $\mathbf{Z}$ & Asymp. Sig. (2-Tailed) & $\mathrm{CZ}$ & SK \\
\hline Formalized personnel strategy & 244298 & -6.281 & 0.000 * & $67.64 \%$ & $51.84 \%$ \\
\hline \multicolumn{6}{|l|}{ Job descriptions } \\
\hline $0-50 \%$ job positions & 257749 & -6.430 & $0.000 *$ & $8.31 \%$ & $19.48 \%$ \\
\hline $51-80 \%$ job positions & 281751 & -1.790 & 0.073 & $12.25 \%$ & $9.36 \%$ \\
\hline $81-90 \%$ job positions & 281466 & -1.627 & 0.104 & $16.18 \%$ & $13.19 \%$ \\
\hline $91-100 \%$ job positions & 274812 & -2.101 & $0.036^{*}$ & $63.26 \%$ & $57.98 \%$ \\
\hline \multicolumn{6}{|l|}{ Information in job descriptions } \\
\hline Purpose of work & 269491 & -3.121 & $0.002 *$ & $70.34 \%$ & $77.45 \%$ \\
\hline Work duties & 271316 & -4.661 & $0.000 *$ & $94.83 \%$ & $88.34 \%$ \\
\hline Authorities & 271102 & -2.597 & 0.009 * & $62.70 \%$ & $56.13 \%$ \\
\hline Responsibility & 273718 & -2.863 & 0.004 * & $84.49 \%$ & $78.83 \%$ \\
\hline Working conditions & 281534 & -1.165 & 0.244 & $40.90 \%$ & $43.87 \%$ \\
\hline Equipment & 283825 & -1.047 & 0.295 & $21.35 \%$ & $19.17 \%$ \\
\hline Requirements & 274115 & -2.149 & $0.032 *$ & $51.69 \%$ & $57.21 \%$ \\
\hline Cooperation & 288715 & -0.207 & 0.836 & $30.34 \%$ & $30.83 \%$ \\
\hline Profile & 284999 & -0.808 & 0.419 & $22.92 \%$ & $24.69 \%$ \\
\hline \multicolumn{6}{|l|}{ Ways of employee adaptation } \\
\hline Work rotation & 274375 & -2.23 & $0.026^{*}$ & $35.96 \%$ & $30.52 \%$ \\
\hline Work programs & 261791 & -4.134 & $0.000 *$ & $34.16 \%$ & $24.39 \%$ \\
\hline Special tasks & 261119 & -4.581 & $0.000 *$ & $27.64 \%$ & $17.64 \%$ \\
\hline Mentoring & 242881 & -6.33 & 0.000 * & $40.00 \%$ & $56.29 \%$ \\
\hline Be thrown in the deep end & 283474 & -1.368 & 0.171 & $13.03 \%$ & $10.74 \%$ \\
\hline Practical examples & 287560 & -0.376 & 0.707 & $30.34 \%$ & $29.45 \%$ \\
\hline \multicolumn{6}{|l|}{ Educational methods } \\
\hline Training & 239711 & -9.22 & 0.000 * & $91.46 \%$ & $74.08 \%$ \\
\hline Video recording & 287945 & -0.494 & 0.622 & $10.11 \%$ & $9.36 \%$ \\
\hline E-learning & 275731 & -2.084 & 0.037 * & $33.03 \%$ & $28.07 \%$ \\
\hline Instruction & 289525 & -0.083 & 0.934 & $42.70 \%$ & $42.48 \%$ \\
\hline Role play & 287935 & -0.601 & 0.548 & $6.74 \%$ & $5.98 \%$ \\
\hline Coaching & 261833 & -4.418 & $0.000 *$ & $28.31 \%$ & $18.56 \%$ \\
\hline Self-education & 262802 & -3.746 & $0.000 *$ & $35.06 \%$ & $44.48 \%$ \\
\hline Model situations & 274267 & -2.53 & 0.011 * & $20.45 \%$ & $25.92 \%$ \\
\hline
\end{tabular}

\footnotetext{
* Statistically significant difference at the 0.05 level (2-tailed).
} 
During a detailed examination of individual personnel processes, we recorded statistically significant differences in several personnel work processes. The existence of a formalized personnel strategy was confirmed by $67.64 \%$ of Czech companies compared to $51.84 \%$ of Slovak companies. Regarding job analysis, there are significant differences in the number of job descriptions for job positions in Czech and Slovak companies. In other words, in the Czech Republic, 92.69\% of companies have prepared job descriptions for more than $50 \%$ of jobs. In Slovakia, it is $80.52 \%$. This fact is a prerequisite for work performance in accordance with the company's strategy. We also calculated the difference in the content of individual job descriptions. While in the Czech Republic, more job descriptions contain work duties, authorities and responsibilities, more job descriptions in the Slovak Republic contain the purpose of work and requirements for employee performance.

Many differences can also be seen in the way of employee adaptation and further training. While companies in the Czech Republic use job rotation, special work programs and solving special tasks, compared to Slovak ones, companies in the Slovak Republic rely mostly on mentoring. Although this method is most often used by companies in the Czech Republic, its use in comparison with other methods is not as significantly common as in the Slovak Republic. Training methods, such as e-learning and coaching are more widely used in the Czech Republic, while in the Slovak Republic self-education and model situations are used.

Based on the above differences, we identify the most frequently solved problems in personnel work and their causes. The most common problems that companies solve in personnel work in both countries include high fluctuation (CR-51.35\%, SR-60.58\%), finding suitable employees on the labor market (CR-32.58\%, SR-41, 72\%) and setting a suitable remuneration system (CR-33.71\%, SR-25.31\%). Therefore, we answered the third research question. The obtained results allow the use in other interpretations, which are not the subject of this article, but could help in solving selected personnel problems.

We were also interested in whether there was a statistical dependence between the most frequently mentioned problems in personnel work and the application of individual personnel activities. We used the Spearman correlation coefficient to verify the dependence. The dependencies between the application of personnel activities and the most frequently identified problems in personnel work are in Tables 4-6. As the results showed minimal differences between the Czech Republic and Slovakia, the data are analyzed. And that's why we were interested in what caused the problems.

The significant dependence of the fluctuation in 9 of the 13 HRM processes is in Table 4 . We expected a positive correlation between the fluctuation and the recruitment resp. and dismissal of employees. This means that the more enterprises engaged in recruiting and/or dismissal of employees, the more likely they mentioned fluctuation as one of the main problems in staffing. In this case, we can understand the mentioned HRM processes as a consequence of the identified problem-fluctuations.

More interesting findings are seen in the case of a negative correlation. We identified this in the case of creating strategies and policies, planning the number of employees, job analysis, adaptation of employees, training, creating a wage system and employee evaluation. In other words, the more companies engage in this HRM process, the less likely they have to deal with high fluctuation issues. We calculated the strongest negative correlation $(-0.348)$ in the analysis of work, followed by planning the number and structure of employees (-0.261). Research and calculations suggest that job analysis and personnel planning can be the most important HRM processes that companies should focus on to reduce fluctuation problems. The remaining four HRM processes did not show a statistically significant correlation with fluctuations. This means that they should have only a minimal impact. These findings are quite debatable, especially in the case of employee care and talent management, because several experts [52-56] et al. 
Table 4. Correlations between HRM processes and fluctuation.

\begin{tabular}{|c|c|c|c|c|c|c|c|}
\hline Fluctuation & 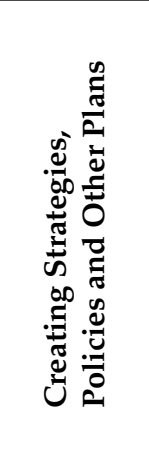 & 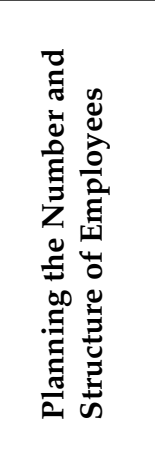 & 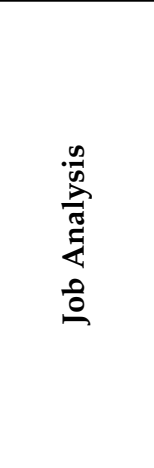 & 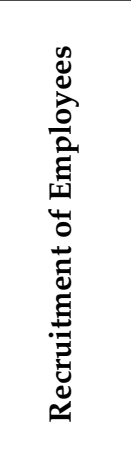 & 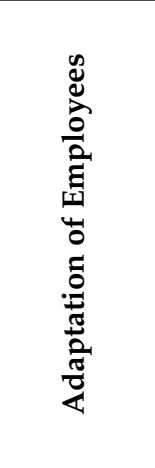 & 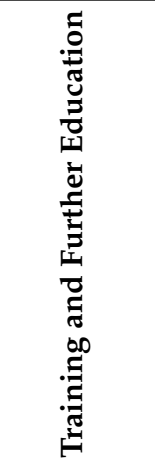 & 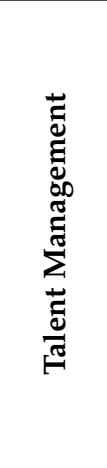 \\
\hline Correlation Coefficient & $-0.129 * *$ & $-0.261^{* *}$ & $-0.348^{* *}$ & $0.418^{* *}$ & $-0.103^{* *}$ & $-0.259^{* *}$ & -0.045 \\
\hline Sig. (2-tailed) & 0.000 & 0.000 & 0.000 & 0.000 & 0.000 & 0.000 & 0.078 \\
\hline $\mathbf{N}$ & 1542 & 1542 & 1542 & 1542 & 1542 & 1542 & 1542 \\
\hline Fluctuation & 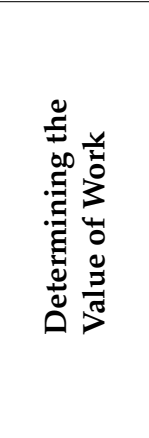 & 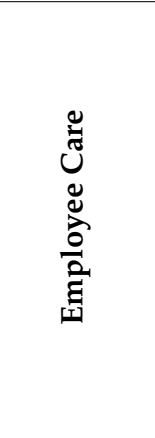 & 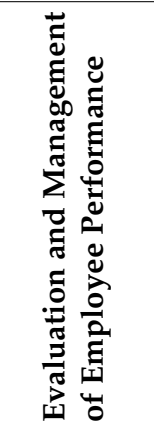 & 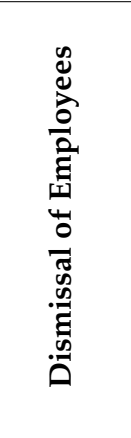 & 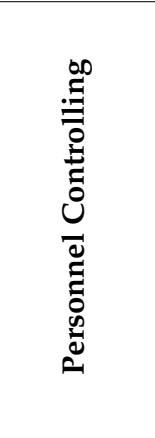 & 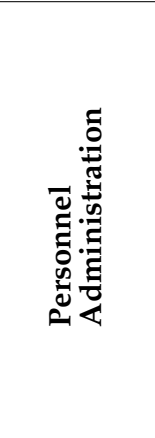 & \\
\hline Correlation Coefficient & $-0.083^{* *}$ & -0.048 & $-0.136^{* *}$ & $0.212^{* *}$ & -0.047 & 0.022 & \\
\hline Sig. (2-tailed) & 0.001 & 0.061 & 0.000 & 0.000 & 0.063 & 0.397 & \\
\hline $\mathbf{N}$ & 1542 & 1542 & 1542 & 1542 & 1542 & 1542 & \\
\hline
\end{tabular}

Table 5. Correlations between HRM processes and searching for employees.

\begin{tabular}{|c|c|c|c|c|c|c|c|}
\hline Searching & 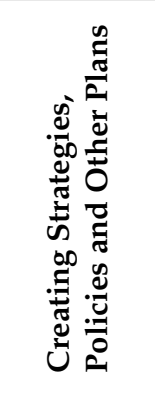 & 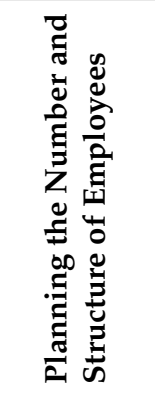 & \begin{tabular}{l}
$\frac{n}{n}$ \\
$\frac{\lambda}{\mathfrak{n}}$ \\
\multirow{2}{*}{} \\
0 \\
0
\end{tabular} & 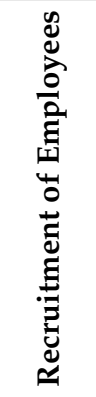 & 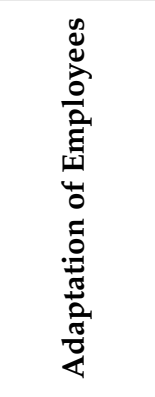 & 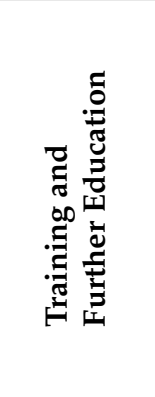 & 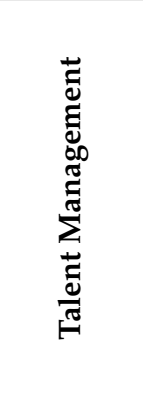 \\
\hline Correlation Coefficient & $-0.114^{* *}$ & $-0.262 * *$ & $-0577^{* *}$ & 0.000 & $-0.165^{* *}$ & $-0.475^{* *}$ & $-0.200 * *$ \\
\hline Sig. (2-tailed) & 0.000 & 0.000 & 0.000 & 0.988 & 0.000 & 0.000 & 0.000 \\
\hline $\mathbf{N}$ & 1542 & 1542 & 1542 & 1542 & 1542 & 1542 & 1542 \\
\hline
\end{tabular}


Table 5. Cont.

\begin{tabular}{|c|c|c|c|c|c|c|}
\hline Searching & 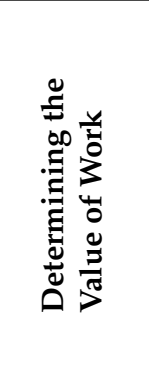 & 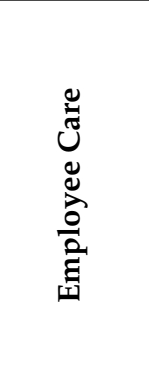 & 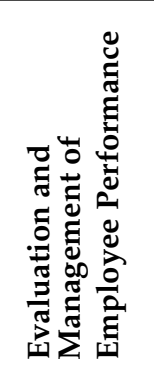 & 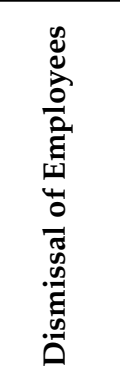 & 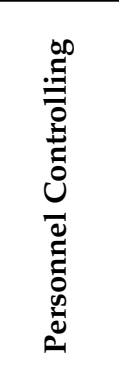 & 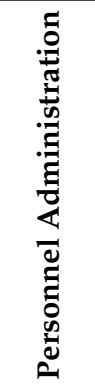 \\
\hline Correlation Coefficient & $-0.159 * *$ & $-0.140 * *$ & $-0.127^{* *}$ & -0.002 & -0.022 & 0.048 \\
\hline Sig. (2-tailed) & 0.000 & 0.000 & 0.000 & 0.929 & 0.378 & 0.058 \\
\hline $\mathbf{N}$ & 1542 & 1542 & 1542 & 1542 & 1542 & 1542 \\
\hline
\end{tabular}

Table 6. Correlations between HRM processes and setting the right reward system.

\begin{tabular}{|c|c|c|c|c|c|c|c|}
\hline Remuneration & 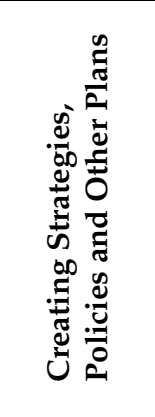 & 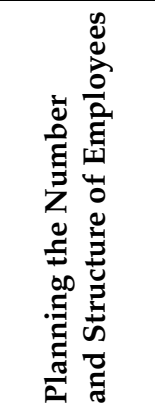 & \begin{tabular}{l}
$\frac{n}{\infty}$ \\
$\frac{\lambda}{2}$ \\
\multirow{3}{*}{} \\
0 \\
0 \\
0
\end{tabular} & 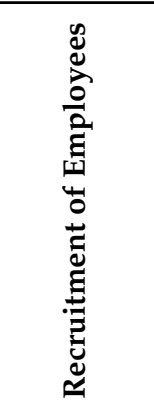 & 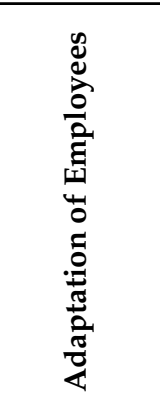 & 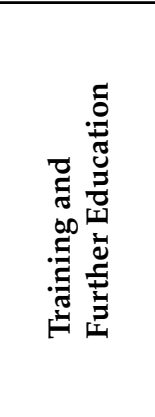 & 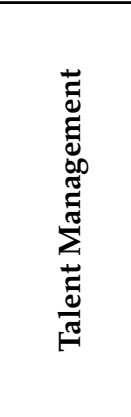 \\
\hline Correlation Coefficient & $-0.138^{* *}$ & $-0.179^{* *}$ & $-0.148^{* *}$ & $-0.108^{* *}$ & $-0.105^{* *}$ & $-0.092^{* *}$ & $-0.055^{*}$ \\
\hline Sig. (2-tailed) & 0.000 & 0.000 & 0.000 & 0.000 & 0.000 & 0.000 & 0.032 \\
\hline $\mathbf{N}$ & 1542 & 1542 & 1542 & 1542 & 1542 & 1542 & 1542 \\
\hline Remuneration & 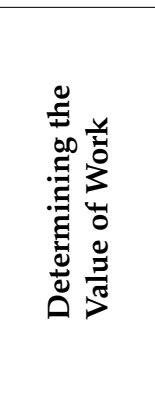 & 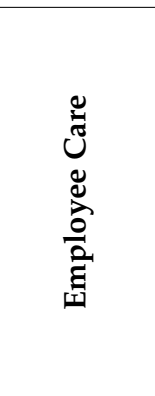 & 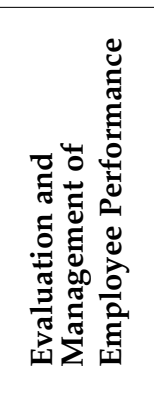 & 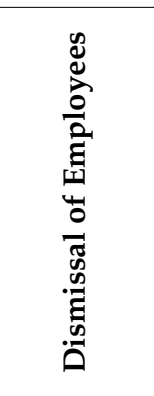 & 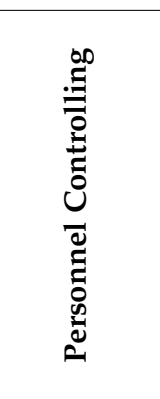 & 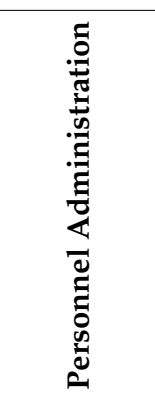 & \\
\hline Correlation Coefficient & $-0.491^{* *}$ & $-0.079 * *$ & $-0.346^{* *}$ & $0.113^{* *}$ & $-0.275^{* *}$ & -0.040 & \\
\hline Sig. (2-tailed) & 0.000 & 0.002 & 0.000 & 0.000 & 0.000 & 0.119 & \\
\hline $\mathbf{N}$ & 1542 & 1542 & 1542 & 1542 & 1542 & 1542 & \\
\hline
\end{tabular}

${ }^{*}$ Correlation is significant at the 0.05 level (2-tailed). ${ }^{* *}$ Correlation is significant at the 0.01 level (2-tailed).

Table 5 presents a significant negative correlation of finding suitable employees in 9 of 13 HRM processes-strategy and policy creation, employee planning, job analysis, employee adaptation, training, talent management, payroll creation, employee care and employee evaluation. It is true that the more companies engage in this HRM process, the less likely they will have difficulty with finding a suitable employee. We again calculated the strongest negative correlation $(-0.577)$ in the analysis of work, but this was followed by training and further education $(-0.475)$. This is quite understandable, as job analysis is the first step in determining accurate and correct criteria for finding a suitable employee. 
The implementation of training and further education indicates that companies reduce the demands on hired employees and prefer to invest in their training or retraining for a specific job. HRM processes in which we did not record a statistically significant correlation with the search for employees are recruitment, dismissal of employees, personnel controlling and personnel administration. Their impact on the problems of finding employees is therefore not demonstrable.

Significant correlations for determining the appropriate remuneration system are in Table 6. The only HRM process that has no significant impact on the problem of creating a remuneration system is the personnel administration. A positive significant correlation was confirmed by dismissing employees. This means that the more often companies identified the remuneration system as a problem, the more often they had to deal with dismissing employees. A negative significant correlation was confirmed in 11 of $13 \mathrm{HRM}$ processes. We recorded the strongest negative correlation $(-0.491)$ in determining the value of work, followed by the evaluation of employees $(-0.346)$. Such a result is not at all surprising since the input information that is necessary for the remuneration system is obtained from the outputs of the two processes. Companies that do not implement them expose themselves to the risk of incorrect setting of parameters for the assessment of work intensity, responsibility at work and the application of the correct criteria, according to which employees are entitled to remuneration.

The human resources managers of subsidiaries, located in the Czech and Slovak Republics unequivocally $(89.92 \%)$, confirmed the benefits obtained from the application of standards, procedures and best practices of multinational companies. On the other hand, they identified areas where problems had occurred: Accounting, taxes and collective bargaining, working time and shift work, length of leave, differences in business negotiation tactics, communication system and maternity/parental leave. Almost 20\% of respondents also pointed to communication barriers in terms of different mental attitudes, non-compliance with work discipline, misunderstanding of priorities, different perceptions of cultural values, indecision or disrespect for the national culture of the country in which they work. A positive trend in multinational companies is the gradual transition from the ethnocentric approach $(21.05 \%)$ to the polycentric $(36.84 \%)$ and transnational $(42.11 \%)$ approach. This trend was also confirmed by a survey of multinational corporations based in Slovakia [49]. In multinational companies, the strategic approach in management prevails $(83.82 \%)$, in local companies, operational management remains $(63.16 \%)$. The reason for the operation, especially in small and medium-sized enterprises, is the daily solution of problems associated with the provision of operations, work discipline, growing fluctuation, inadequate competencies of employees. Managers of large local companies pay more attention to the creation of HRM strategies and policies (162), 56.17\% of them have a developed strategy. The obtained results answered the research question number 4.

The trend of introducing a sustainable approach to HRM is reflected in both multinational and local companies. An important part of this approach is employer branding, which is associated with building a good name, strong brand, a good relationship with supervisors and employees, developing a strong corporate culture, support and customer service, employer value proposition for potential and current employees. Subsidiaries $(62.75 \%)$ have many years of experience in building the employer's brand, taking over examples of best practice from the parent company and applying them mainly in the process of recruitment, evaluation and compensation, career development, training, employee empowerment, job safety and innovative employer-new work practices. While in multinational companies employer branding predominates, based on attracting and retaining quality and talented employees, local companies, due to the higher rate of fluctuation, use human resource marketing $(80.16 \%)$, to fill a specific job with a suitable candidate for work in the company.

The human resources managers of the surveyed multinational and local companies agree that if they want to achieve sustainable business competitiveness, they must pay attention to employees, effectively use their skills, support creativity, create conditions for 
motivation and job satisfaction. The pre-requisites for success to achieve this goal are the skills and competencies of managers. Local businesses must also learn how to implement a strategic and sustainable approach to personnel work. The solution of common operational problems is unsystematic, it takes managers a lot of working time, which can be used more effectively to create a strategy and vision of the company, setting values that are accepted by employees and customers.

\section{Discussion and Conclusions}

Personnel work in Slovakia and the Czech Republic underwent significant changes after 1989. In the business sphere, a uniform, centrally managed policies and procedures for carrying out HR processes have been replaced by tools that are in the competence of company management. As there is a growing number of multinational companies and the impact of internationalization, examples of good practice from the world-successful companies are reflected in HRM. From operational management, the application of strategic, sustainable and holistic approaches to HRM is gradually approached. In general, it is possible to say that HRM activities in both countries have begun to be used more effectively to meet the needs of employers and employees themselves.

The results of the research show that in the Czech Republic, HRM is strategically approached, while in Slovakia, operational processes are primarily addressed. Therefore, we came to the conclusion that the level of personnel work in the Czech Republic is higher than in the Slovak Republic. Our statement is based on a comparison of individual developmental stages of personnel work, specifically personnel management and human resources management. Human resources management, as the last, so far the highest stage of personnel work, is basically a business-oriented philosophy, in order to achieve a competitive advantage, applies a strategic approach, requires the alignment of the company's overall strategy with the human resources strategy [57]. This corresponds to our findings on the level of personnel work in companies in the Czech Republic. Managers understand the strategic approach as harmonization of HRM practice and strategic enterprise goals, and a strategic approach towards the effective employment and development of a highly committed and qualified workforce to achieve the company's objectives. On the other hand, in the stage of personnel management, personnel work remains mostly focused on internal company problems, employment of people and workforce management. Little attention is paid to strategic issues of workforce management, employment in the company and the impact of the environment. Personnel work is more of an operational management nature and relies mainly on personnel departments [58]. We have identified these characteristic features of personnel work in most companies in the Slovak Republic. Respondents' views are in line with research studies abroad. The most important HRM processes in the Czech Republic include recruitment and adaptation (91.69\%), evaluation and management of employee performance $(89.89 \%)$, job analysis $(76.40 \%)$, creation of strategies, policies and other plans $(74.83 \%)$ and planning the number and structure of employees $(74.61 \%)$. In Slovakia, the most important processes include operational orientation processes such as recruitment $(80.21 \%)$, personnel administration $(72.70 \%)$, recruitment and adaptation $(70.25 \%)$, planning the number and structure of employees $(69.79 \%)$, training and further education (69.02\%). The reason for employee fluctuation in the Slovak Republic is the underestimation of strategy and plans, insufficient support for talent management and further education of employees.

The management of personnel administration and recruitment can be professionally provided by outsourcing by a personnel agency and the management will create a space for more conceptual management. Underestimation of the creation of a formalized personnel strategy and job descriptions for individual positions is another reason for leaving the job. In the Czech Republic, approximately two-thirds of companies have a formalized personnel strategy, in the Slovak Republic only about half. About $92 \%$ of companies in the Czech Republic have prepared job descriptions for more than 50\% of jobs, in Slovakia, it is in almost $81 \%$ of companies. On the contrary, for more than $90 \%$ of job positions, job 
descriptions are recorded by almost two-thirds of Czech companies, compared to $57.98 \%$ of Slovak ones. Similarly, we have identified differences in the way of employee's adaptation and further training that may affect fluctuations in both countries. Businesses in the Czech Republic use more flexible methods for adaptation, such as job rotation, special work programs and the solution of special tasks; training, e-learning and coaching predominate in further education. These methods of adaptation and education are not so strongly represented in Slovak companies, which can be a problem especially concerning the future sustainability of the skilled workforce.

HRM managers in the Czech and Slovak Republics confirmed the application of the trend towards a holistic approach toward working with people in the work processes and similarly to [59]. This new direction of personnel work, emphasizes the importance of people, the human labor force as the most important factor of production. A positive finding of the survey of personnel work in Slovakia, despite the predominance of the operation, is the fact that in larger companies and multinational companies, new trends and tendencies are beginning to be applied more, which change the procedures of performing specific HRM processes. Personnel work is becoming more qualified, more flexible and more modern, it focuses more on aligning the ideas of management with the needs of employees, internal customers of the company. Examples of good practice involve the use of electronic HRM, the introduction of specific approaches to personnel work, based on digital technologies and gamification, especially in the processes of acquisition and further education. New trends and approaches of managers to HRM open up space for further research, which we expect to carry out in the V4 countries. The issue of balancing globally standardized MNC policies with the specificities of the local context also remains unresolved. In assessing the level of IHRM, several authors [60,61] point to the cultural differences of individual countries. We are of the opinion that insufficient attention is paid to MNCs in examining satisfactory or unsatisfactory national differences. Our intention is also to examine the rules of division of labor within MNCs and to focus on the impact of national effects on the concept of IHRM in MNCs.

Author Contributions: L.S. and M.V. conceived and designed the article; L.S., M.V., Š.Č., V.M. collected, analysed and interpreted the data; L.S., M.V., Š.Č., V.M. wrote the article; L.S. and M.V. formally edited the article. All authors have read and agreed to the published version of the manuscript.

Funding: This research was funded by the Scientific Grant Agency of the Ministry of Education, Science, Research and Sport of the Slovak Republic and the Slovak Academy of Sciences as part of project VEGA 1/0116/18 "Convergence and divergence in international human resource management" and by the Silesian University in Opava as part of the Student Grant System SGS/06/2018 "Economics Literacy of Business Entities".

Institutional Review Board Statement: Not applicable.

Informed Consent Statement: Informed consent was obtained from all subjects involved in the study.

Data Availability Statement: The data presented in this study are available on request from the corresponding author. The data are not publicly available due to their sensitivity.

Conflicts of Interest: The authors declare no conflict of interest.

\section{References}

1. Transformation of Economics: Slovak Experience; Institute of Slovak and World Economy of the Slovak Academy of Sciences: Bratislava, Slovakia, 2005. Available online: http:/ / www.ekonom.sav.sk (accessed on 15 July 2019).

2. Vetráková, M. Proces zmien v personálnom manažmente (The process of changes in personnel management). Ekon. Časopis 1998, $46,560-573$.

3. Kachaňáková, A. Human Resource Management; Ekonom: Bratislava, Slovakia, 1999.

4. Stýblo, J. Modern Human Resources; Grada: Prague, Czech Republic, 1998.

5. $\quad$ Lorincová, S.; Hitka, M.; Štarchoň, P.; Stachová, K. Strategic Instrument for Sustainability of Human Resource Management in Small and Medium-Sized Enterprises Using Management Data. Sustainability 2018, 10, 3687. [CrossRef]

6. Storey, J. Human Resource Management: A Critical Text; Thomson Learning: London, UK, 2007.

7. ̌nezníček, J. Scientific Organization Work; Svoboda: Prague, Czech Republic, 1970. 
8. Bach, S. Managing Human Resources. Personnel Management in Transition; Blackwell Publishing: Oxford, UK, 2005.

9. Prescott, R.K.; Rothwell, W.J. The Encyclopedia of Human Resource Management; Pheiffer: San Francisco, CA, USA, 2012.

10. Thomas, D.C.; Lazarova, M.B. Essentials of International Human Resource Management: Managing People Globally. Essent. Int. Hum. Resour. Manag. Manag. People Glob. 2013, 23-46. [CrossRef]

11. Knezović, E.; Bušatlić, S.; Riđić, O. Strategic human resource management in small and medium enterprises. Int. J. Hum. Resour. Dev. Manag. 2020, 20, 114. [CrossRef]

12. Ehnert, I.; Parsa, S.; Roper, I.; Wagner, M.; Muller-Camen, M. Reporting on sustainability and HRM: A comparative study of sustainability reporting practices by the world's largest companies. Int. J. Hum. Resour. Manag. 2016, 27, 88-108. [CrossRef]

13. Donate, M.J.; Peña, I.; De Pablo, J.D.S. HRM practices for human and social capital development: Effects on innovation capabilities. Int. J. Hum. Resour. Manag. 2015, 27, 928-953. [CrossRef]

14. Hitka, M.; Kucharčíková, A.; Štarchoň, P.; Balážová, Ž.; Lukáč, M.; Stacho, Z. Knowledge and Human Capital as Sustainable Competitive Advantage in Human Resource Management. Sustainability 2019, 11, 4985. [CrossRef]

15. Afiouni, F. Human capital management: A new name for HRM? Int. J. Learn. Intellect. Cap. 2013, 10, 18. [CrossRef]

16. Gerasimov, V.O.; Sharafutdinov, R.I.; Kolmakov, V.; Erzinkyan, E.A.; Adamenko, A.A.; Vasilyeva, A.G. Control in the human capital management system in the strategy of innovative development of a region. Entrep. Sustain. Issues 2019, 7, 1074-1088. [CrossRef]

17. Pyatt, G.; Becker, G.S. Human Capital: A Theoretical and Empirical Analysis, with Special Reference to Education. Econ. J. 2006, 76, 635. [CrossRef]

18. Habib, M.; Abbas, J.; Noman, R. Are human capital, intellectual property rights, and research and development expenditures really important for total factor productivity? An empirical analysis. Int. J. Soc. Econ. 2019, 46, 756-774. [CrossRef]

19. Armstrong, M.; Taylor, S. Armstrong's Handbook of Human Resource Management Practice; Kogan Page: London, UK; New York, NY, USA, 2020.

20. Boon, C.; Eckardt, R.; Lepak, D.P.; Boselie, P. Integrating strategic human capital and strategic human resource management. Int. J. Hum. Resour. Manag. 2018, 29, 34-67. [CrossRef]

21. Bierema, L.L.; Callahan, J.L. Transforming HRD. Adv. Dev. Hum. Resour. 2014, 16, 429-444. [CrossRef]

22. Iqbal, A. The strategic human resource management approaches and organisational performance: The mediating role of creatie climate. J. Adv. Manag. Res. 2019, 16, 181-193. [CrossRef]

23. Gander, M. Improving employee satisfaction through human resource management. Perspect. Policy Pr. High. Educ. 2019, 23, 37-38. [CrossRef]

24. Dessler, G. Human Resource Management; Pearson: Boston, MA, USA; London, UK, 2013.

25. Dickmann, M.; Brewster, C.; Sparrow, P. International Human Resource Management; Routledge: London, UK; New York, NY, USA, 2016.

26. Tarique, I.; Briscoe, D.R.; Schuler, R. International Human Resource Management: Policies and Practices for Multinational Enterprises; Routledge: London, UK, 2016.

27. Kramar, R. Beyond strategic human resource management: Is sustainable human resource management the next approach? Int. J. Hum. Resour. Manag. 2014, 25, 1069-1089. [CrossRef]

28. Chams, N.; García-Blandón, J. On the importance of sustainable human resource management for the adoption of sustainable development goals. Resour. Conserv. Recycl. 2019, 141, 109-122. [CrossRef]

29. Malá, D.; Sedliačiková, M.; Drábek, J.; Jelačić, D.; Minárová, M. Consumer perception of environmentally sustainable products of Slovak wood processing enterprises. Drv. Ind. 2019, 70, 407-418. [CrossRef]

30. Wikhamn, W. Innovation, sustainable HRM and customer satisfaction. Int. J. Hosp. Manag. 2019, 76, 102-110. [CrossRef]

31. Amrutha, V.; Geetha, S. A systematic review on green human resource management: Implications for social sustainability. $J$. Clean. Prod. 2020, 247, 119131. [CrossRef]

32. Lee, J.; Kim, S.; Lee, J.; Moon, S. Enhancing Employee Creativity for A Sustainable Competitive Advantage through Perceived Human Resource Management Practices and Trust in Management. Sustainability 2019, 11, 2305. [CrossRef]

33. Roscoe, S.; Subramanian, N.; Jabbour, C.J.; Chong, T. Green human resource management and the enablers of green organisational culture: Enhancing a firm's environmental performance for sustainable development. Bus. Strat. Environ. 2019, 28, 737-749. [CrossRef]

34. Drucker, P.F.; Macciariello, J.A. The Daily Drucker: 366 Days of Insight and Motivation for Getting the Right Things Done; Elsevier Butterworth-Heinemann: Oxford, UK, 2004.

35. Zhang, L.; Guo, X.; Lei, Z.; Lim, M.K. Social Network Analysis of Sustainable Human Resource Management from the Employee Training's Perspective. Sustainability 2019, 11, 380. [CrossRef]

36. Pham, N.T.; Tučkova, Z.; Phan, Q.P.T. Sectoral Analysis of The Effectiveness of Bank Risk Capital in The Visegrad Group Countries. J. Bus. Econ. Manag. 2019, 20, 446-465. [CrossRef]

37. Pfeffer, J. Seven Practices of Successful Organizations. Calif. Manag. Rev. 1998, 40, 96-124. [CrossRef]

38. Becker, B.; Gerhart, B. The Impact of Human Resource Management on Organizational Performance: Progress and Prospects. Acad. Manag. J. 1996, 39, 779-801. [CrossRef]

39. Rizov, M.; Croucher, R. Human resource management and performance in European firms. Camb. J. Econ. 2008, 33, 253-272. [CrossRef] 
40. Mira, M.S.; Choong, Y.V.; Thim, C.K. The effect of HRM practices and employees' job satisfaction on employee performance. Manag. Sci. Lett. 2019, 9, 771-786. [CrossRef]

41. Njoku, E.; Ruël, H.; Rowlands, H.; Evans, L.; Murdoch, M. An Analysis of the Contribution of e-HRM to Sustaining Business Performance; Emerald Publishing Limited: Bingley, UK, 2019; pp. 21-39.

42. Waheed, A.; Miao, X.; Waheed, S.; Ahmad, N.; Majeed, A. How New HRM Practices, Organizational Innovation, and Innovative Climate Affect the Innovation Performance in the IT Industry: A Moderated-Mediation Analysis. Sustainability 2019, 11, 621. [CrossRef]

43. Brown, C.; McManus, C.; Davison, I.; Gill, P.; Lilford, R. Using recruitment and selection to build a primary care workforce for the future. Educ. Prim. Care 2019, 30, 128-132. [CrossRef]

44. Dany, F.; Torchy, V. Policy and Practice in European Human Resource Management; Informa UK Limited: London, UK, 2017; pp. 68-88.

45. Noe, R.A.; Hollenbeck, J.R.; Gerhart, B.; Wright, P.M. Human Resource Management: Gaining a Competitive Advantage; McGraw-Hill Education: New York, NY, USA, 2017.

46. Šikýr̆, M. The Best Practices in Human Resource Management; Grada Publishing: Prague, Czech Republic, 2014.

47. Vetráková, M.; Smerek, L.; Seková, M. The importance of human resources management in business practice in Slovakia. In Proceedings of the 30th International Business Information Management Association Conference, Madrid, Spain, 8-9 November 2017.

48. European Commission. Directive 2012/27/Eu of the European Parliament and of the Council of 25 October 2012 on the Energy Efficiency, Amending Directive 2009/125/EC and 2010/30/EU and Repealing Directives 2004/8/EC and 2006/32/EC (Text with EEA Relevance). Available online: http:/ / eur-lex.europa.eu (accessed on 15 July 2019).

49. Kasuya, E. Mann-Whitney U test when variances are unequal. Anim. Behav. 2001, 61, 1247-1249. [CrossRef]

50. Nachar, N. The Mann-Whitney U: A Test for Assessing Whether Two Independent Samples Come from the Same Distribution. Tutor. Quant. Methods Psychol. 2008, 4, 13-20. [CrossRef]

51. Kafadar, K.; Sheskin, D.J. Handbook of Parametric and Nonparametric Statistical Procedures. Am. Stat. 1997, 51, 374. [CrossRef]

52. Narayanan, A.; Rajithakumar, S.; Menon, M. Talent Management and Employee Retention: An Integrative Research Framework. Hum. Resour. Dev. Rev. 2018, 18, 228-247. [CrossRef]

53. Björkman, I.; Ehrnrooth, M.; Mäkelä, K.; Smale, A.; Sumelius, J. Talent or Not? Employee Reactions to Talent Identification. Hum. Resour. Manag. 2013, 52, 195-214. [CrossRef]

54. McDonald, K.; Hite, L. Career Development: A Human Resource Development Perspective; Routledge: New York, NY, USA, 2016.

55. Sonnenberg, M.; Van Zijderveld, V.; Brinks, M. The role of talent-perception incongruence in effective talent management. J. World Bus. 2014, 49, 272-280. [CrossRef]

56. Shengxian, Y.; Change, L.; Hui, Y.; Xiao, Y.; Jianxin, R. Work-Related Identity Discrepancy and Employee Turnover Intention: The Mediation Effect of Job Satisfaction. Int. J. Bus. Soc. Sci. 2019, 10. [CrossRef]

57. Koubek, J. Human Resource Management; Management Press: Prague, Czech Republic, 2015.

58. Werther, J.; Davis, K. Human Resources and Personnel Management; McGraw-Hill: New York, NY, USA, 1996.

59. Hecklau, F.; Galeitzke, M.; Flachs, S.; Kohl, H. Holistic Approach for Human Resource Management in Industry 4.0. Procedia CIRP 2016, 54, 1-6. [CrossRef]

60. Edwards, T.; Kuruvilla, S. International HRM: National business systems, organizational politics and the international division of labour in MNCs. Int. J. Hum. Resour. Manag. 2005, 16, 1-21. [CrossRef]

61. Morley, M.J.; Heraty, N. The Anatomy of an International Research Collaboration: Building Cumulative Comparative Knowledge in Human Resource Management. Int. Stud. Manag. Organ. 2019, 49, 341-354. [CrossRef] 